\title{
Breast Cancer pN0 TNM Finding v6
}

National Cancer Institute

\section{Source}

National Cancer Institute. Breast Cancer pNO TNM Finding v6. NCI Thesaurus. Code C48991.

Breast cancer without histological evidence of regional lymph node involvement (no isolated tumor cell cluster greater than $0.2 \mathrm{~mm}$ ), and in which no examination for isolated tumor cells is performed. (from AJCC 6th Ed.) 